Article

\title{
The European Commission as a Policy Entrepreneur under the European Semester
}

\author{
Bernhard Zeilinger \\ University of Applied Sciences BFI Vienna, Austria; E-Mail: bernhard.zeilinger@fh-vie.ac.at
}

Submitted: 30 January 2021 | Accepted: 13 July 2021 | Published: 30 July 2021

\begin{abstract}
This article discusses the impact that the reforms of the European Union's economic governance since 2011 have had on the European Commission's role as a policy entrepreneur. Particular attention is paid to mechanisms that are applied by the Commission to extend its scope beyond its given formal competences to shape national reform agendas. The research interest is based on the assumption that the Commission is a 'competence-maximising rational actor' (Pollack, 1997), whose primary organisational goals are to expand the scope of Community competence and increase the Commission's own standing within the policy process. Accordingly, this research contributes to the scholarly debate by identifying mechanisms applied by the Commission under the European Semester to shape European and national reform agendas in areas of sovereign policymaking competences of the member states.
\end{abstract}

\section{Keywords}

economic governance; European Commission; European Semester; policy entrepreneurship; soft law

\section{Issue}

This article is part of the issue "Resilient Institutions: The Impact of Rule Change on Policy Outputs in European Union Decision-Making Processes" edited by Ariadna Ripoll Servent (University of Salzburg, Austria) and Angela Tacea (Vrije Universiteit Brussel, Belgium).

(C) 2021 by the author; licensee Cogitatio (Lisbon, Portugal). This article is licensed under a Creative Commons Attribution 4.0 International License (CC BY).

\section{Introduction}

In the aftermath of the financial and economic crisis, several changes were made to the EU's economic governance. In an immediate response to the crisis, the EU Council agreed on far-reaching institutional changes with the reform packages of the 'Six Pack' (2011) and 'Two Pack' (2013). The reforms aim to strengthen fiscal discipline, based on fiscal rules and macroeconomic indicators, and increase reform pressure in areas of national competencies such as economic, fiscal, labour market, and social policies.

The noteworthy changes enhanced the discretionary authority of the Commission and the Council to push for structural reforms in EU member states by addressing macroeconomic imbalances (Erne, 2018, p. 237; Scharpf, 2014). Macroeconomic coordination was improved by integrating soft-governed policy issues, such as labour market and social policy, into the regime of hardgoverned fiscal policy (Barcevičius et al., 2014, pp. 34-35;
Copeland \& Daly, 2015; Crespy \& Menz, 2015; de la Porte \& Heins, 2015, p. 12). Many authors have described this as a subordination of social policy objectives to the priorities of the latter, such as fiscal discipline and economic productivity (Bruff, 2017; Crespy \& Menz, 2015, pp. 199-200; Degryse et al., 2013, p. 70; Hacker, 2019, p. 56; Syrovatka, 2016, p. 33; Wigger, 2015). Based on that, the European Semester has become the focal point for reform discussions in Europe that aim to achieve the goals of the Europe 2020 strategy and the Euro-Plus Pact (de la Porte \& Heins, 2015). The reform agenda is substantiated by expertise-driven Country-SpecificRecommendations (CSRs). Deciding on CSRs, however, is a collaborative process between Commission and Council. The Commission formulates a draft and the Council, on behalf of the member states, decides on this soft law. To ensure the member states' commitment and, thus, compliance with the CSRs, once passed, it is crucial to involve them at every stage during the European Semester. 
In 2015, under the Juncker presidency in the Commission, several measures were introduced for fostering dialogue and information gathering with various actors from member states, primarily with social partners in accordance with guideline seven and principle eight of the European Pillar of Social Rights (EPSR; European Commission, 2016). Important innovations include the establishment of European Semester Officers (ESOs), as part of Commission delegations in each member state. The ESOs consult with national policymakers and social partners separately in their fact-finding missions, discussing policy developments in their countries and including this information when drafting the annual CSRs. Furthermore, the Commission's Directorate-General for Employment, Social Affairs and Inclusion (DG EMPL) and the Employment Committee (EMCO), representing the member states, conduct regular tripartite joint reviews with member states and national social partners on Country Reports and CSRs (Eihmanis, 2017).

Although the Semester was suspended in response to the Covid-19 pandemic and its severe impact on the economic development, a new instrument was introduced that might further increase the Commission's role as a policy entrepreneur. With Regulation 2021/241, the EU Council agreed to establish a temporary financial instrument under the budgetary line of the 'NextGenerationEU,' called the Recovery and Resilience Facility. Member states benefit from the support of the Recovery and Resilience Facility if their reform plans contribute to the Commission's policy guidelines.

The underlying argument of this article is that the paramount importance of these changes and their potential impact on the political and bureaucratic function of the Commission call for a reopening of the debate concerning the entrepreneurial role of the Commission in facilitating structural reforms in areas of national competence. The research contributes to this debate by examining how the Commission uses its new role under the European Semester to strategically exploit instruments and strategies and enhance its ability to mobilise both consensus for the Commission's reform proposals and commitment among supranational and national policymakers. It does so despite institutional asymmetries and structural power imbalances in decision-making with its inter-institutional counterparts in the Council.

\section{The Conceptual Framework: Mechanisms of Policy Entrepreneurship in a Multilevel Governance}

This article attempts to generate insights on the empirical patterns by which the Commission exerts reform pressure on member states under the European Semester, its role being limited to coordinating policy reforms in areas that are entirely in the competence of the member states. This section starts from the premise that the Commission benefited from changes made to the economic governance, which enabled it to become an effective policy entrepreneur.
In the literature, a policy entrepreneur is described as an individual or collective actor who might be based within the government system (politicians or civil servants) or outside it (interest groups; Gunn, 2017, p. 265). A policy entrepreneur "seeks policy change that shifts the status quo in given areas of public policy" (Mintrom, 2015 , p. 103) by influencing key players in the decision making (Cohen, 2012, p. 9). The European Semester includes several innovations that have clearly enhanced the Commission's capacity to shape the reform agenda in areas in the domain of member states, such as labour market and social policy. Research has so far highlighted the entrepreneurial role of the Commission in economic policymaking (Chang \& Monar, 2013; Ferrera, 2017), focusing on the economic crisis and its impact on policy change (Saurugger \& Terpan, 2016) and analysing the entrepreneurship of the Directorate-General for Economic and Financial Affairs (DG ECFIN) within the Commission in economic governance (Maricut \& Puetter, 2018; Schön-Quinlivan \& Scipioni, 2017). So far, there has been no research done into the entrepreneurial role of the Commission under the European Semester. This article delves into the formulation and adoption of CSRs as the instrument to shape national reform agenda and contributes to the research area by identifying mechanisms that enhance the capacity of policy entrepreneurs to shape policymaking in a multilevel governance setting.

The analytical framework borrows from the 'multiplestreams framework' of John Kingdon (2011), used for a structured description of the involvement of policy entrepreneurs in policy formation ranging from problem identification to interpretation of problems and, further, to the negotiation of specific policy responses. The 'multiple-streams framework' describes policymaking along three streams called 'problem stream,' 'politics stream,' and 'policy stream' each offering distinct 'policy windows' for policy entrepreneurs to shape policymaking (Petridou, 2014, p. 20). The problem stream focuses on factors that have an influence on the identification and interpretation of a policy problem and open a window of opportunity for policy entrepreneurs. These factors can include specific events that change the salience of issues and the feedback on policies from stakeholders on policies. Furthermore, the creation of a technocratic procedures, based on strict assessment guidelines and indicators, as well, can also have a huge impact on the identification and interpretation of problems. Based on these considerations, a first hypothesis is formulated as follows:

$\mathrm{H} 1$ : The more a problem identification and interpretation takes place within strict assessment guidelines and indicators, the more likely it will be put on the agenda by the policymakers.

Policy entrepreneurs benefit from a technocratic approach in a veto-prone setting. In technocratic governance regimes, proposals based on statistics and 
facts are difficult for policymakers to ignore or to argue against without referring to empirical evidence. In any case, policy entrepreneurs depend on detailed and specific policy knowledge. Policy entrepreneurs are in regular consultation with all kinds of political actors, such as policymakers, interest groups, and other policy entrepreneurs to gather information. Further, the more a policy entrepreneur is able to gain far-reaching political support from other stakeholders, such as interest groups, the more a policy proposal is perceived as legitimate and the harder it is for policymakers to ignore or veto. Therefore, policy entrepreneurs actively seek to form policy communities or epistemic communities, as they are an important source of knowledge and legitimacy (Hartlapp et al., 2010, p. 20).

$\mathrm{H} 2$ : The more policy entrepreneurs gather country and policy knowledge from relevant policy communities, the more their proposals are perceived as more legitimate.

As discussed by Kingdon (2011), the likelihood of a policymaker to succeed in putting a policy problem on top of the agenda relates to the political costs associated with it. Political costs of any decision relate to the salience and acceptability of a policy to the general public and are expressed by public opinion, electoral votes, consent by party clientele, and reputation of the policymaker (Kingdon, 2011, pp. 66, 147). Therefore, policymakers will prefer decisions with low political costs for them. The less politicised a policy, the less the political costs. Consequently, technocratic procedures and a low obligation to implement decisions ease the adoption by policymakers as their decision is of less consequence. Besides, as discussed by Kingdon (2011, pp. 184-186), it is advisable to focus on a manageable number of policy problems, as a policymaker can only process a limited number of projects at any given time. It might be the case that policymakers pick policy problems of little political cost and avoid the ones with high political costs. Therefore, less is more and a policy entrepreneur should anticipate policymakers' constraints when raising policy proposals.

Furthermore, as stated by the 'actor-centred institutionalism' (Mayntz \& Scharpf, 1995), institutional rules and values have an influence on how policy entrepreneurs are empowered to mobilize their optional power resources. Optional power resources are defined here as the ability of actors to increase political costs for policymakers in case of deviant action by legal enforcement powers as well as to mobilise peer pressure (Treib, 2015). The decision-making rules play a crucial role in this context. It matters if it is possible for the decisionmakers to amend or reject a proposal and if the decision to be agreed is vague and non-binding rather than strict and of binding force, with possible sanctions in place. The ability to mobilize peer pressure is another power resource that is a result of shared beliefs between the policy entrepreneur and relevant political actors and epistemic communities (Scharpf, 2000, p. 77). In a multilevel setting, the decision-making includes several actors of distinct political power. Consequently, if the policy entrepreneur shares its belief with the more powerful actors, peer pressure might evoke and ease the consent of reluctant policymakers. A good example for asymmetric imbalance of power in governance regimes is the 'EU core-periphery model' at the member state level. The argument here is as follows: If the Commission's CSRs address member states in the periphery, it might be easy to mobilise peer pressure among the more powerful core member states. With that in mind, our third hypothesis is claimed:

$\mathrm{H} 3$ : The less politicised and the less binding a decision is the more likely policymakers will vote in favour of the peer group.

On the contrary, the more controversial a policy and the more precise in wording as well as binding in the scope of action needed, the more hesitant decision makers will be to agree. Conversely, this means that a policy entrepreneur needs to seek for ownership first, to make a policy effective. The main instruments for generating ownership are: firstly, gaining the consent of policymakers to the procedure and the indicators to assess policy developments; secondly, anticipating policy preferences as well as general preferences of policymakers and using these for the policy entrepreneur's strategic advantage; thirdly, ensuring significant involvement of policymakers in the identification and interpretation of policy problems as well when formulating the policy proposal. That means that policymakers have to have a chance to intervene or argue at a preliminary stage. However, once a policy proposal is adopted, policy entrepreneurs will refer to the ownership of policymakers if the policy is to be implemented. If policymakers are not willing to do so, their reputation will be permanently damaged.

H4: Policy entrepreneurs seek to involve policymakers at every stage of the policy formation aiming to increase their ownership of the proposal when it is due to be implemented.

The final stream of the 'multiple-stream framework' is the policy stream, which focuses on the formation and negotiation of specific policy responses. This stream is more policy oriented and here the 'coupling process' (Kingdon, 2011, pp. 180-181) comes into play. This concept is applied by policy entrepreneurs to shape the agenda setting by presenting their favourite policy to the policymakers as a solution to the detected problem at the right moment (Knaggård, 2015, p. 450). This is because it is quite helpful if the policy entrepreneur is able to influence the process of identifying and interpreting policy problems and to narrow policy options down to a limited set of possible solutions (Ackrill et al., 2013). This relates to a specific technocratic capture potential 
that a policy entrepreneur has to define specific assessment indicators, use procedural rules to put its interpretation first on the agenda, and mobilise peer pressure.

H5: The higher the technocratic capture potential of policy entrepreneurs, the more likely they are able to streamline policy debates according to their own policy preferences by coupling identified problems with the right policy solution.

Figure 1 summarizes the findings of the theoretical discussion by structuring the causal mechanisms in relation to the distinct stage of the policymaking and the differences between mechanisms based on procedural rules and on political interaction.

In the following sections, the theoretical claims are qualified by an inference analysis on applied mechanisms of policy entrepreneurship, as demonstrated in Figure 1. These mechanisms are tested against the practice of economic governance under the European Semester. To achieve this, the empirical analysis relies on the findings from 14 semi-directed expert interviews carried out with senior officials at the Commission, advisory committees to the Council (EMCO) and involved social partners between December 2020 and May 2021 (the list of interviewees is in the Supplementary File). Interviewees were asked to describe how the Commission works under the rules of the European Semester and how it cooperates with the Council, the member states executives, and social partners, in order to increase the significance of its policy proposals. Furthermore, the main findings from the interviews were discussed with leading academics in the field of interest to qualify the arguments and conclusions made in the article. The author would like to thank Amy Verdun, Bart Vanhercke, Sebastiano Sabato, Jörg Haas and Felix Syrovatka for their helpful comments.

\section{Empirical Analysis}

In this section, the author takes a 'mechanismic perspective' (Gerring, 2008) by empirically uncovering the causal pathways on how the Commission exerts influence as a policy entrepreneur. The empirical analysis scrutinises the rule change implemented with the 'Six Pack' (2011) and 'Two Pack' (2013), the reforms to the procedure at the beginning of the Juncker Commission (2015) and, finally, the establishment of the Recovery and Resilience Facility in 2021. The theoretical argument is that, with the changes made to the economic governance, the Commission's role as a policy entrepreneur was strengthened as follows. Firstly, the commission gained a higher direct impact on the European reform agenda due to new treaty-based competences under the European Semester. Secondly, the Commission made strategic endeavours to extend its scope for shaping policy decisions beyond formal rules and in areas of national competence such as the labour market and social policy. The empirical analysis sheds light on the strategic endeavours of the Commission to use its optional power resources within the rules of procedure and political interaction. The research analyses strategic attempts by the Commission to increase its influence on policymaking by scrutinizing its role in the procedure and its interaction with other actors along three stages of the policy cycle: 1) policy identification and interpretation, 2) policy formulation and negotiation, and 3) policy implementation.

\subsection{Policy Identification and Interpretation: Streamlining Policy Debates}

The European Semester starts with two main monitoring reports: The Alert Mechanism Report and the Joint Employment Report annexed to the Annual Growth Survey. The Alert Mechanism Report includes the findings of an examination by the Commission based on a scoreboard of 14 macroeconomic indicators. Specific thresholds are set, in order to define the appropriate development in a country. If a country's development is below or above this threshold, the Commission conducts 'In-Depth Reviews.' Consequently, countries with severe macroeconomic imbalances could face an 'Excessive Imbalance Procedure.' Thus, indicators play a
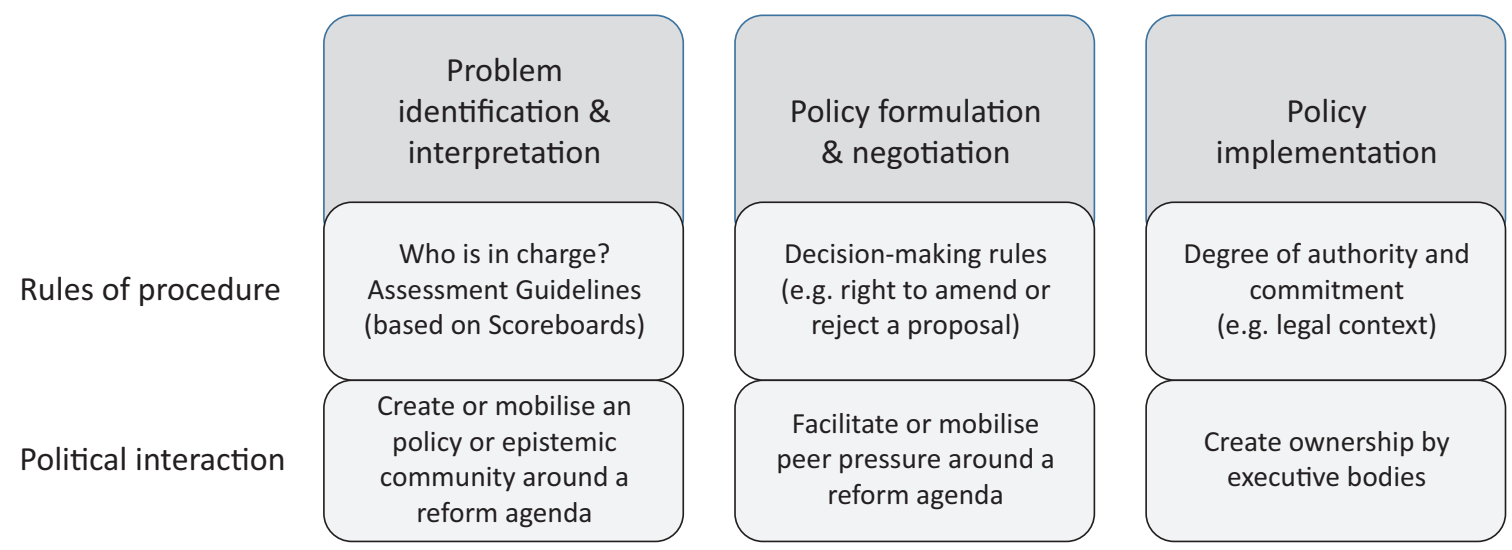

Figure 1. The 'multilevel policy entrepreneur' mechanisms of policy reform. 
crucial role in shaping reform agendas. Although they are perceived as being technocratic in form and objective, the agreement on them has been highly political and often a compromise between France and Germany (Bokhorst, 2019, pp. 118-120). The Commission performs the scrutiny based on the indicators but is free to interpret the findings and thus uses them to frame policy discourses. Its conclusion is published in the so-called Country Reports. They serve as the basis for tailor-made CSRs for member states that address reform demands in economic, fiscal, employment or social policy areas. Member states are requested to implement them within 12-18 months. The Commission's draft CSRs have to receive the consent of the Council to be adopted.

The Commission's interpretation, therefore, has to be backed by specific policy and country knowledge. For the former, DG EMPL on behalf of the Commission has strengthened its intelligence-gathering and analytical capacity through the development of new monitoring instruments and the intensification of multilateral surveillance by establishing different benchmarking tools such as the Europe 2020 Joint Assessment Framework for monitoring the Employment Guidelines, the Social Protection Performance Monitor and the Employment Performance Monitor. The Employment Performance Monitor is a bi-annual joint report of DG EMPL together with EMCO, which summarises the assessment of the Europe 2020 Joint Assessment Framework and identifies key challenges. Another important innovation has been the establishment of the EPSR in 2017, based on 20 principals. Since 2018, the Joint Employment Report is drawn up according to twelve Social Scoreboard indicators based on these 20 principles. Although the DG EMPL and the Council configuration on Employment, Social Policy, Health and Consumer Affairs (EPSCO) together agree on using EPSR as the reference for social CSRs, member states seem very reticent. As Hacker (2019, p. 55) found out, only eleven member states consider them when formulating their National Reform Programme (NRP). In addition, DG EMPL published several proposals to emphasise its reform agenda, which were discussed, monitored, and reviewed within the European Semester. Foremost among these were the 'Employment Package' (2012), the 'Compact for Growth and Jobs' (2012), the 'Youth Employment Package' (2012) and the 'Social Investment Package' (2013). Furthermore, individual DGs also have their own monitoring reports to address their specific policy demands. A good example is the debate on the effective and statutory retirement age. DG EMPL and DG ECFIN each provide their own expertise on this issue. Whereas DG EMPL produces a so-called adequacy report every two years, which is adopted at the advisory committee to the Council EPSCO, DG ECFIN draws up the so-called ageing report to emphasise its own agenda on this issue.

With the Juncker Commission (2014-2019), the Commission intensified the information exchange with political communities (Haas, 1992; Zito, 2001). The
Commission opened several channels for gathering country-specific information, and for discussing findings of the annual monitoring, expressed in the so-called Country Reports. The most important of these are annual fact-finding missions and the establishment of responsible contact persons at the Commissions delegation in each country, the so-called ESOs. In addition, the Commission conducts bipartite and tripartite meetings with country representatives to gain all-encompassing information as well as to increase its ownership with the CSRs. The involvement and consultation of national stakeholders, especially social partners, are a crucial source of expertise and legitimacy that strengthens the Commission's role as a policy entrepreneur (Interview DG EMPL \#1 and SECGEN \#6; Tricart, 2019). As for the involvement of trade unions, the European Trade Union Confederation (ETUC) is most notably involved in ex-ante consultation when drafting the Annual Growth Survey and the Joint Employment Report (Interview ETUC \#7). The ETUC is also invited to meet with the Troika of the EU during the informal EPSCO Council. Their cooperation was formalised in a cooperation protocol in 2014 (Interview DG EMPL \#1). Furthermore, the Commission financially supported the launch of Trade Union Semester Liaison Officers (TUSLOs) for a more streamlined communication. TUSLOs are the main representatives of their organisation in coordinating Semester policies at the EU level, especially within the ETUC, and in acting as a central contact at the national level.

The traditional arenas for neo-corporatist practices at the EU level are the European Economic and Social Committee (EESC) and the European Social Dialogue (ESD). The EESC has acknowledged the growing importance of the European Semester and replaced its Europe 2020 Steering Committee with the European Semester Ad hoc Group. The European Semester Ad hoc Group coordinates the work of the EESC sections and takes a position on Semester documents by using existing access to actors around EU's economic governance. The ESD, however, is not used for consultation between European social partners on issues related to the European Semester. In fact, the EESC and ESD play no decisive role because the consultation between social partners and the Commission still takes place bilaterally (Sabato, 2020). Although multiple points of access along the multilevel system are open to social partners within the European Semester, the most effective one is still the national social dialogue. But its significance has diminished especially in countries that enjoy a strong social dialogue anyway, such as Austria, Germany, and Finland (Kirov \& Markova, 2020; Pavolini \& Natili, 2020; Sabato, 2020).

Furthermore, in light of the limited enforcement authority in labour market and social policy domains, a deliberative and inclusive approach is applied to increase national ownership and politicisation of CSRs with contributing to effective compliance with CSRs. This approach counteracts the practice of behind-closed- 
doors decision-making on NRPs and the dominance of finance ministers. As a result, the Commission strengthened its efforts to involve social partners by calling on the national governments to consult social partners more effectively in drawing up NRPs and the National Job Plan (Eurofound, 2019). After this, governments were obliged to annex the views of social partners to those documents. In any case, most governments are bypassing social partners when drafting their NRPs, including in the current recovery plan (Interview ECOSOC \#9 and TUSLO \#6).

These measures are interpreted as endeavours to politicise CSRs at the national level with the help of social partners and, hence, increase reform pressure on national governments (Erne, 2019). Moreover, the interventionist tendencies associated with the European Semester regime also favour the politicization along national rather than transnational class lines (Jordan et al., 2020, p. 3). It is therefore questionable whether the current institutionalisation of civil society participation offers an appropriate remedy to the problems of democracy and accountability from which the EU suffers. The vertical surveillance under the European Semester put countries in competition with one another, which implicitly constitutes a deterrent to transnational Euro-corporatism. Effective interest intermediation and influence presuppose a shared agenda accumulated within the respective social partner organisations. Nevertheless, different national circumstances make it difficult to develop a joint agenda at the ETUC. The main cleavages are based on the different economic models in each country, divided between those that are more demand-side or supply-side oriented. In particular, trade unions in many member states are sceptical about recognising the European Semester as a legitimate policy process. Several interviewees from trade unions (Interview TUSLO \#12 and TUSLO \#8), underlined the demand for the democratisation of the European Semester by including the European parliament as well as national parliaments into the decision making. Current consultations of social partners are merely on an ad-hoc basis and not seen as effective for having a say in the agenda building; a regular dialogue would be needed for that.

Trade unions, in particular, accept DG EMPL as an honest broker for their interests (Interview TUSLO \#12). Nevertheless, trade unions criticise the limitation in scope and regularity of their interaction (Sabato et al., 2017). They criticise a lack of access to other thematic DGs involved in the process, like DG ECFIN or SECGEN (Interview ETUC \#7). Furthermore, trade unions propose the expansion of economic governance to include other policy areas, such as environment, industry, and education, in order to discuss employees' interests in a more comprehensive manner (Interview TUSLO \#12). In addition, the interaction with the Commission is described as asymmetric, spontaneous, and without any commitment. As described in the interviews, DG EMPL consults trade unions proactively and regularly. Trade unions are invited to tripartite talks during fact-finding missions and to discussions of Country Reports and CSRs. Often, trade unions are consulted on an ad-hoc basis, when DG EMPL needs specific information (Interview TUSLO \#12). Although trade unions deliver requested information, they regret the absence of an ex-post dialogue as well as any commitment to their proposals by DG EMPL and, thus, their lack of impact on final decisions (Interview TUSLO \#12). Consequently, social partners often feel instrumentalised by DGs' agendas and do not see a reliable cooperation, because relevant transparent procedures are missing (Interview TUSLO \#12).

To sum up, it is the technocratic notion set up by the assessment guidelines and the competence given to the Commissions as well as their regular consultation with social partners which strengthens the Commission's proposals and thus, clearly shapes the decision-making of the Council on CSRs.

\subsection{Policy Formulation and Negotiation: The Commission's True Agenda-Setting Power}

The insistence on the implementation of a revamped integrated coordination and surveillance framework reflects both the extension of the scope of coordination, which is due to an expansion to include labour market and social policy areas, and its intensification, which is due to enhanced surveillance and peer pressure (Maricut \& Puetter, 2018, p. 198). The reform packages of the 'Six Pack' (2011) and 'Two Pack' (2013) provide crucial competences to the Commission to administer the European Semester and to prepare the basis for any decision by the Council. The Commission's preferences are substantiated by formulating the CSRs. CSR formation at the level of the Commission is built upon expertise and transparent indicator-based monitoring. Apparent independent expertise, based on information-gathering and indicator-based interpretation, serves as the justification of CSRs (Interview DG EMPL \#1). CSRs find their legitimisation through their reference to other public monitoring reports, like the Alert Mechanism Report and the Joint Employment Report annexed to the Annual Growth Survey, and benchmarks formulated in the Europe 2020 and Euro-Plus Pact. Soft-law, used to coordinate labour market and social policies, was merely integrated into the logic of hard governance of fiscal policy (Kahn-Nisser, 2015) and the coordination process became more characterised by 'command-and-control' attitudes whereby "national diversity is often placed within strict limits with high levels of supranational policy prescription" (Dawson, 2015, p. 984).

One widely discussed argument is that the empowerment of the Commission is an attempt by 'core' member states (Gräbner et al., 2018, p. 19)-such as Germany, Netherlands, and Denmark-to utilise the Commission as a strategic agency to discipline member states into maintaining sound public finances and push them to implement requested structural reforms according to an ordoliberal agenda (Ryner, 2015). In this 
view, the European Semester is intended to help in putting pressure on indebted member states (e.g., Italy, Spain, Portugal, and Greece) to conduct reforms in the policy areas that account for the main shares of budgetary expenditures, such as unemployment compensation and social allowances. Furthermore, the argument runs, these reforms are supposed to contribute to the EU's objective to gain productivity by, for example, ensuring lower unit labour costs and higher flexibility on the labour market. Overall, the article argues that core member states facilitate peer pressure on the periphery to accept the new economic governance regime and its policy objectives by integrating its economic models into the logic of the European Semester. Furthermore, in 2015, as part of broader efforts to streamline the European Semester, the number of CSRs was reduced to two to five overall recommendations per country to increase reform pressure on prioritised CSRs (Vanhercke et al., 2015). It is thought that putting emphasis on the most prioritised CSRs is a good strategy to evoke peer pressure in the tradition of the Open Method of Coordination (OMC) strategy of blaming and shaming concerning the monitoring of progress on pre-defined benchmarks.

It should be emphasised that the Commission draws on its technocratic capture potential through substantial in-house policy and country expertise, built up through administering the coordination of the Lisbon and Europe 2020 process under the OMC, which relies on a deliberative, consensus-seeking, and expertise-driven approach. The Commission benefits from its "familiarity with the challenge of debating its positions with the economic policy actors under the Integrated Guidelines of the Lisbon Strategy" (Zeitlin \& Vanhercke, 2018, p. 165).

With the launch of the Lisbon Strategy in 2000, the Commission was entrusted with the facilitation of policy coordination among member states on the OMC-principles. The purpose of this coordination is to harmonize member states' policies along mutually agreed benchmarks while guaranteeing them their sole sovereign power to govern in these policy areas. In 2010, the ill-fated Lisbon Strategy was succeeded by the ten-year reform agenda Europe 2020, which defines five numerical headline targets, mainly addressing social cohesion. In addition, member states agreed on the Euro-Plus Pact that addresses more than 50 reform proposals in twelve key areas aiming to increase productivity and economic growth in the European Single Market. Member states are encouraged to include them into their annual NRP and have to report to the Commission on the progress achieved and on the challenges encountered. The policy coordination under the OMC clearly falls short of expectations. It is the Commission's task to identify and negotiate on jointly agreed benchmarks and monitor the progress made by member states in fulfilling them. But the Commission lacks any enforcement authority under the OMC. Any policy change in the member states relies mainly on soft power as policy learning through the exchange of best practices and expertise.
One way of increasing compliance pressure is to incorporate unbinding recommendations into the logic of what appears to be hard governance. Subsequently, macroeconomic coordination builds upon a precise monitoring of member states compliance with defined benchmarks and entails enforcement duties in case of policy failure. It is the Commission who is in charge of monitoring member states' macroeconomic development and identifying severe imbalances. Each year, the Commission publishes its results and clusters countries according to the extent of their macroeconomic imbalances. This is reminiscent of the mechanism of blaming and shaming that has been used under the OMC. Nevertheless, the Commission's role as policy entrepreneur benefits from the changes made by the Semester's procedural framework. Although the cooperation between the Commission (DG EMPL) and the EPSCO Council has gradually been shaped by institutional asymmetries based on distinct legal contexts of their competences, it has turned into a collaborative setting, facilitated by the consensus-seeking nature of the advisory committee to the Council EMCO (Zeitlin \& Vanhercke, 2018, p. 151). Therefore, the EMCO is seen as an important resource for the Commission to evoke peer pressure as decisions are made collectively and on the basis of the Commission's evidence-based problem interpretation (Interview DG EMPL \#1 and SECGEN \#6). The consensus at EMCO is a crucial resource of ownership (Interview DG EMPL \#1 and EMCO \#2).

Interaction between the DG EMPL of the Commission and national governments takes place at two main venues. First, they seek consultation with national governments during its annual fact-finding missions while formulating its Country Reports. These fact-finding missions are organised by the ESOs at the Commission delegations in the member states and include dialogues with national governments and administrations as well as social partners. Second, the advisory EMCO prepares EPSCO conclusions on the Annual Growth Survey (including the Joint Employment Report) and on CSRs in the employment field. The EMCO is a senior expert committee that consists of representatives from member states and is supported by DG EMPL. EMCO enjoys crucial consensus-generating capacities and draws its strength from close and regular cooperation between senior experts from member states' ministries and DG EMPL. Two sub-groups support it: the policy analysis group, which provides advice on EMCO work, and the indicators group, which carries out technical work related to the indicators that are used to monitor the implementation of EU's employment strategy. Their role is seen as very important, as indicators are used to justify policy recommendations. To conclude, member states are involved at various stages of the Semester cycle. They adopt indicators, used to identify macroeconomic imbalances, have to adopt CSRs, and can veto an excessive imbalance procedure. But the process is highly standardised and technocratic. Therefore, once the process has started, it is 
hardly possible for a member state to veto on CSRs. Changes to the Commissions' proposal on CSRs need a double majority in the Council, which is virtually unreachable without a good reason (Interview SECGEN \#6). And, although they are not binding, once in place, it is almost impossible to remove CSRs from the agenda and, thus, member states have to reflect on them until they are implemented (Interview ETUC \#7). As another interviewee points out "once on the list, it is difficult to get them off the list" (Interview TUSLO \#8).

To conclude this section, it is very difficult to reject or change a proposal made by the Commission. Most of its proposals gain support by the core and creditor states for two reasons. First, CSRs gain impact in case of severe macroeconomic imbalances. Most of the states who face severe macroeconomic imbalances are from the so-called European periphery. Second, indicators used for the assessment are mainly negotiated among core member states and, thus, follow their policy objectives. To sum up, it is about the Commission's technocratic capture potential to be able to emancipate from core member states' agenda.

\subsection{Policy Implementation: How to Ensure the Significance of CSRs}

This section asks about the significance of CSRs on national reform agendas, as their proposed effectiveness has a direct impact on the decision-making. The argument here is, the more binding a CSR, the more difficult to get it through the Council. Although the Commission enjoys far-reaching agenda-setting competences, it reveals little about its effective implementation into national reform agendas. Due to a database provided by the Commission's Economic Governance Support Unit of the Directorate-General for Internal Policies, only 51.6 percent of CSRs were satisfyingly implemented in average between 2012 and 2019 . Furthermore, the compliance rate declined from 71 percent in 2012 to 39.8 percent in 2019 (Directorate-General for Internal Policies, 2020). The lack of enforcement capabilities fits into the debate on the 'post-Maastricht integration paradox,' which states that member states seek closer integration in order to address undeniable policy interdependencies, but without transferring real powers such as legislative competences to supranational actors (Maricut \& Puetter, 2018, p. 206). Instead, they prefer collective agreement on coordination objectives by enhancing the consensus-generation capacity of high-level intergovernmental forums in areas outside the classic community method-namely economic governance, employment, and social affairs (Maricut \& Puetter, 2018, p. 195).

Some of the CSRs themselves have gained more significance because of a legal context referring to the Macroeconomic Imbalance Procedure and/or the Stability and Growth Pact and their corrective arms 'Excessive Imbalance Procedure' for the former and
'Excessive Deficit Procedure' for the latter. As a study by Bekker $(2015$, p. 13) and Maricut and Puetter (2018, p. 205) has shown, at least 50 percent of social CSRs are addressed under a legal context. Member states are requested to implement them within 12-18 months. The national Ministries of Finance are primarily responsible for implementation because most of the proposed reforms have implications for the budget (Interview DG EMPL \#1; Kudrna \& Wasserfallen, 2020). Furthermore, a positive conditionality as well might help to increase the compliance with CSRs. A good example is the recently established Resilience and Recovery Facility that provides financial assistance for funding the implementation of reforms who address CSRs (Interview TUSLO \#6).

Apart from that, the Commission puts efforts to increase the consent among member states under a vetoprone procedure. The challenge, therefore, is to formulate CSRs that get the ownership of member states. This includes a regular communication relying on data-based expertise and specific policy knowledge. To enhance national ownership of the supranational reform agenda, the Commission underpins CSRs through wide-ranging consultation with national administrations, ensuring that CSRs are robust enough to withstand scrutiny (Verdun \& Zeitlin, 2018, p. 145). The governance of the Semester has likewise become less hierarchical and more interactive, while the CSRs, especially in the social and employment field, have become less uniform, less prescriptive, and better adapted to national circumstances (Zeitlin \& Vanhercke, 2018, p. 168).

Finally, since 2015, the Commission involves social partners more closely in the Semester cycle. Forming political communities with national social partners, which provide the Commission with specific policy and country knowledge, should also help to politicise the technocratic Semester Cycle on the member state level and mobilise publicity of CSRs and, thus, bring them on the national reform agenda. To conclude here, CSRs are not binding, but they raise attention to crucial shortcomings of a state and, thus, may be referenced in domestic political debates by political actors to blame the government or to increase reform pressure. Currently, the politicisation is the highest in countries of the periphery (e.g., Italy) that face severe reform pressure by legally binding CSRs.

The main conclusion to be made here is that CSRs linked to severe macroeconomic imbalances are of binding force with possible legal consequences in case of a lack of compliance by national policymaking. The challenge, however, is to gain impact on the policymaking in all member states, despite the legal context of the CSRs. On one hand, the Commission aims to increase national ownership with the Semester procedure and the CSRs. The involvement of social partners, on the other hand, should help to increase political costs for policymakers at the national level in case of a lack of implementation (see also Ferrera, 2017). 


\section{Conclusion}

It was the aim of this article to uncover the entrepreneurial role gained by the Commission with the reform of the economic governance. Initially, therefore, a theoretical model of distinct mechanisms (Figure 1) by which a policy entrepreneur might shape multi-level policymaking was developed in the first place. The model and delineated hypothesis were used to investigate Commission's entrepreneurial role under the European Semester. The empirical analysis was mainly based on document analysis and semi-structured expert interviews.

First, it was hypothesised that policy entrepreneurs are more successful in agenda-setting when this process is highly technocratic. The analysis has shown that the European Semester procedure is highly standardised. Political debates on the formulation of CSRs are based on indicators and specific policy as well as country knowledge. Although such technocratic procedures seem to be less politicized, the author underlines the high degree of politicisation when setting specific indicators that streamline policy debates within prioritized norms and values. Furthermore, the Commission was able to increase its technocratic capture potential by juxtaposing the political logic of hard governance with streamlining agenda building in areas of soft governance on the 'command and control' principle. Its impact relies on its empowered role under the European Semester regime, in which it is in charge of identifying and interpreting policy problems as well as offering justified solutions substantiated by CSRs. This is illustrated by clear benchmarks, assessment frameworks, and monitoring reports. Second, and connected to the Commissions' technocratic capture potential, reference is made to the gained policy and country knowledge that forms the Commission's expertise. Of importance are regular and meaningful consultations with social partners, which have been intensified since 2015 and strengthen Commission's political power when discussing its proposed CSRs.

Third, peer pressure is an important factor under the European Semester. The research has shown some evidence that the European Semester is of asymmetric significance to member states, depending on whether the latter are confronted by severe budget and/or macroeconomic imbalances. As discussed by Ryner (2015) and others, initially, the Commission was empowered in the economic governance to serve the agenda of core member states. Nonetheless, our findings show that since the Commission under Juncker (2014-2019), the Commission has emancipated itself from core member states' agendas and developed its own policy priorities such as substantiated in the EPSR. Nevertheless, the research lacks any evidence so far that the Commission is able to mobilise specific peer pressure in the Council to its favour. Apart from that, we still face a huge politicization in the Council when it comes to decisions on the corrective arms of the Semester.
Our fourth hypothesis refers to Commission's aim to increase the compliance with CSRs at member state level. The Commission interacts closely with national governments and includes them at every stage of the agenda building to gain their consent to the final CSRs. The aim is to increase national ownership to the fullest extent and to de-politicize reform debates at the EU-level by means of expertise-driven proposals. On the other hand, our final finding refers to the Commission's attempt to enable a meaningful involvement by social partners at the national level. Although on a weaker level, evidence is given that the Commission seeks, by the involvement of stakeholders, to politicize CSRs in member states. The Commission's strategic aim is to bring CSRs onto the national reform agenda and, thus, increase the effectiveness of macroeconomic policy coordination under the European Semester.

To conclude, this research contributes to the literature by shedding light on how the Commission expands its impact on national policymaking beyond its given competences. The elaborated model should help to guide further research into the mechanisms applied to reach effective impact on national reform agendas.

\section{Acknowledgments}

The author would like to thank the anonymous referees as well as the editors for their very helpful suggestions, comments, and advice. Many thanks also to the Austrian Chamber of Labour for its funding.

\section{Conflict of Interests}

The author declares no conflict of interests.

\section{Supplementary Material}

Supplementary material for this article is available online in the format provided by the author (unedited).

\section{References}

Ackrill, R., Kay, A., \& Zahariadis, N. (2013). Ambiguity, multiple streams, and EU policy. Journal of European Public Policy, 20(6), 871-887.

Barcevičius, E., Weishaupt, T., \& Zeitlin, J. (Eds.). (2014). Assessing the open method of coordination. Institutional design and national influence of EU social policy coordination. Palgrave Macmillan.

Bekker, S. (2015). European socioeconomic governance in action: Coordinating social policies in the third European Semester (OSE Research Paper No. 19). European Social Observatory.

Bokhorst, J. (2019). Governing imbalances in the economic and monetary union: A political economy analysis of the macroeconomic imbalance procedure. [Doctoral thesis, University of Amsterdam]. UvA-DARE. https://dare.uva.nl/search?identifier $=85$ 
d7b956-00d5-47ac-95d2-284115ca9bbf

Bruff, I. (2017). Cease to exist? The European 'social' model and the hardening of 'soft' EU law. In C. Tansel (Ed.), States of discipline. Authoritarian neoliberalism and the contested reproduction of capitalist order (pp. 149-169). Rowman and Littlefield.

Chang, M., \& Monar, J. (Eds.). (2013). The European Commission in the post-Lisbon era of crises-Between political leadership and policy management. P.I.E. and Peter Lang.

Cohen, N. (2012). Policy entrepreneurs and the design of public policy: The case of the national health insurance law in Israel. Journal of Social Research and Policy, 3(1), 1-22.

Copeland, P., \& Daly, M. (2015). Social Europe: From 'add-on' to 'dependence-upon' economic integration. In A. Crespy \& G. Menz (Eds.), Social policy and the Euro crisis: Quo Vadis social Europe (pp. 140-160). Palgrave Macmillan.

Crespy, A., \& Menz, G. (2015). Commission entrepreneurship and the debasing of Social Europe before and after the Eurocrisis. Journal of Common Market Studies, 53(4), 753-768.

Dawson, M. (2015). The legal and political accountability structure of 'post-crisis' EU economic governance. Journal of Common Market Studies, 53(5), 976-993.

Directorate-General for Internal Policies. (2020). Country-specific recommendations: An overviewSeptember 2020 (Briefing to the European Parliament/ PE 624.404).

Deganis, I. (2007). The politics behind consensus: Tracing the role of the Commission within the European employment strategy. Journal of Contemporary European Research, 2(1), 21-40.

Degryse, C., Jepsen, M., \& Pochet, P. (2013). The Euro crisis and its impact on national and European social policies (Working Paper 5). European Trade Union Institute.

de la Porte, C., \& Heins, E. (2015). A new era of European integration? Governance of labour market and social policy since the sovereign debt crisis. Comparative European Politics, 13(1), 8-28.

Eihmanis, E. (2017). Cherry-picking external constraints: Latvia and EU economic governance, 2008-2014. Journal of European Public Policy, 25(2), 231-249.

Erne, R. (2018). Labour politics and the EU's new economic governance regime. Transfer, 24(2), 237-247.

Erne, R. (2019). How to analyse a supranational regime that nationalises social conflict? In E. Nanopoulos \& F. Vergis (Eds.), The crisis behind the Euro-crisis (pp. 346-368). Cambridge University Press.

Eurofound. (2019). The involvement of social partners in national policymaking. Publications Office of the European Union.

European Commission. (2016). A new start for social dialogue. One year after. Publications Office of the European Union. https://doi.org/10.2767/003952

Ferrera, M. (2017). Impatient politics and social invest- ment: The EU as 'policy facilitator.' Journal of European Public Policy, 24(8), 1233-1251.

Gerring, J. (2008). The mechanismic worldview: Thinking inside the box. British Journal of Political Science, 38(1), 161-179.

Gräbner, C., Heimberger, P., Kapeller, J., \& Schütz, B. (2018). Structural change in times of increasing openness: Assessing path dependency in European economic integration (Working Paper Series 76). ICAE.

Gunn, A. (2017). Policy entrepreneurs and policy formulation. In M. Howlett \& I. Mukherjee (Eds.), Handbook of policy formulation (pp. 265-282). Edward Elgar.

Haas, P. M. (1992). Introduction: Epistemic communities and international policy coordination. International Organization, 46(1), 1-35.

Hacker, B. (2019). A European Social Semester? The European Pillar of Social Rights in practice (Research report). European Trade Union Institute.

Hartlapp, M., Metz, J., \& Rauh, C. (2010). How external interests enter the European Commission: Mechanisms at play in legislative position formation. Social Science Research Center Berlin (WZB).

Jordan, J., Maccarrone, V., \& Erne, R. (2020). Towards a socialization of the EU's new economic governance regime? EU labour policy interventions in Germany, Ireland, Italy and Romania (2009-2019). British Journal of Industrial Relations, 59(1), 191-213.

Kahn-Nisser, S. (2015). The hard impact of soft coordination: Emulation, learning, and the convergence of collective labour standards in the EU. Journal of European Public Policy, 22(10), 1512-1530.

Kingdon, J. W. (2011). Agendas, alternatives and public policies. Longman.

Kirov, V., \& Markova, E. (2020). Channels for trade union involvement in the European Semester (Analytical Report Work Package 5). European Social Observatory.

Knaggård, Å. (2015). The multiple streams framework and the problem broker. European Journal of Political Research, 54(3), 450-465.

Kudrna, Z., \& Wasserfallen, F. (2020). Conflict among member states and the influence of the Commission in EMU politics. Journal of European Public Policy, 28(6), 902-913.

Maricut, A., \& Puetter, U. (2018). Deciding on the European Semester: The European Council, the Council and the enduring asymmetry between economic and social policy issues. Journal of European Public Policy, 25(2), 193-211.

Mayntz, R., \& Scharpf, F. (1995). Der Ansatz des akteurzentrierten Institutionalismus [The actorcentred institutionalism]. In R. Mayntz \& F. Scharpf (Eds.), Gesellschaftliche Selbstregelung und politische Steuerung [Self-regulation of political governance] (pp. 39-72). Campus.

Mintrom, M. (2015). Policy entrepreneur and morality politics: Learning from failure and success. In I. Narbutaité Aflaki, E. Petridou, \& L. Miles (Eds.), 
Entrepreneurship in the polis. Understanding political entrepreneurship (pp. 103-117). Ashgate.

Pavolini, E., \& Natili, M. (2020). Towards a stronger relationship between national social dialogue and the European Semester? (Analytical Report Work Package 3). European Social Observatory.

Petridou, E. (2014). Theories of the policy processContemporary scholarship and future directions, Policy Studies Journal, 42(1), 12-32.

Pollack, M. A. (1997). Delegation, agency, and agenda setting in the European Community. International Organization, 51(1), 99-134.

Ryner, M. (2015). Europe's ordoliberal iron cage: Critical political economy, the euro area crisis and its management. Journal of European Public Policy, 22(2), 275-294.

Sabato, S., Vanhercke, B., \& Spasova, S. (2017). Listened to, but not heard? Social partners' multilevel involvement in the European Semester. European Social Observatory.

Sabato, S. (2020). Opening up the European Semester? Trade unions between 'Brussels' and domestic politics (Final report of the INVOTUNES project). European Social Observatory.

Saurugger, S., \& Terpan, F. (2016). Do crises lead to policy change? The multiple streams framework and the European Union's economic governance instruments. Policy science, 49(1), 35-53.

Scharpf, F. W. (2000). Interaktionsformen: Akteurszentrierter Institutionalismus in der Politikforschung [Forms of interaction: Actor-centred institutionalism in policy research]. Leske \& Budrich.

Scharpf, F. W. (2014). Political legitimacy in a nonoptimal currency area. In O. Cramme \& S. B. Hobolt (Eds.), Democratic politics in a European Union under stress (pp. 19-47). Oxford University Press.

Schön-Quinlivan, E., \& Scipioni, M. (2017). The Commission as policy entrepreneur in European economic governance: A comparative multiple-stream analysis of the 2005 and 2011 reform of the Stability and Growth-Pact. Journal of European Public Policy, 24(8), 1172-1190.

Syrovatka, F. (2016). Die Reformpolitik Frankreichs in der Krise. Arbeitsmarkt- und Rentenpolitik vor dem Hintergrund europäischer Krisenbearbeitung [The reform policy of France during the crisis. Labour market and pension policy at the background of European crisis policy]. Springer.

Treib, O. (2015). Akteurszentrierter Institutionalismus [Actor-centred institutionalism]. In G. Wenzelburger \& R. Zohlnhöfer (Eds.), Handbuch Policy-Forschung [Handbook of policy research] (pp. 277-303). Springer.

Tricart, J.-P. (2019). Legislative implementation of European social partner agreements: Challenges and debates (Working paper 2019.09). European Trade Union Institute.

Vanhercke, B., Zeiltin, J., \& Zwinkels, A. (2015). Further socializing the European Semester: Moving forward for the 'Social Triple A'? European Social Observatory.

Verdun, A., \& Zeitlin, J. (2018). Introduction: The European Semester as a new architecture of EU socioeconomic governance in theory and practice. Journal of European Public Policy, 25(2), 137-148.

Wigger, A. (2015). Enhancing 'competitiveness' in response to the European crisis: A wrong and dangerous obsession. In J. Jäger \& E. Springler (Eds.), Asymmetric crisis in Europe and possible futures (pp. 114-130). Routledge.

Zeitlin, J., \& Vanhercke, B. (2018). Socializing the European Semester: EU social and economic policy co-ordination in crisis and beyond. Journal of European Public Policy, 25(2), 149-174.

Zito, A. R. (2001). Epistemic communities, collective entrepreneurship and European integration. Journal of European Public Policy, 8(4), 585-603.

\section{About the Author}

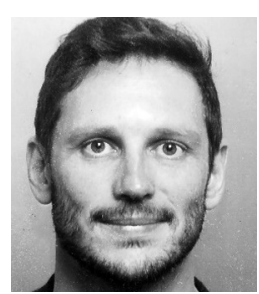

Bernhard Zeilinger is a Researcher at the University of Applied Sciences BFI Vienna. He holds a PhD from the Vienna University in Political Science. After obtaining his PhD, he joined the Institute for European Integration Research at the Austrian Academy of Sciences as a Post-Doctoral Fellow. His current research agenda focuses on the socio-economic governance regime of the EMU in the areas of social and labor market policies and, further, how interest groups adapt to the new realities under the European Semester. 